\title{
Invading parasites: spillover of an alien nematode reduces survival in a native species
}

\author{
Claudia Romeo (1) - Anna Pia Piscitelli 1 - Francesca Santicchia $($ i) \\ Adriano Martinoli (i) Nicola Ferrari (iD) Lucas A. Wauters $(\mathbb{D}$
}

Received: 19 March 2021 / Accepted: 23 July 2021 / Published online: 12 August 2021

(C) The Author(s) 2021

\begin{abstract}
It is widely assumed that spillover of alien parasites to native host species severely impacts naïve populations, ultimately conferring a competitive advantage to invading hosts that introduced them. Despite such host-switching events occurring in biological invasions, studies demonstrating the impact of alien macroparasites on native animal hosts are surprisingly few. In Europe, native red squirrels (Sciurus vulgaris) are replaced by introduced North American grey squirrels ( $S$. carolinensis) mainly
\end{abstract}

Supplementary Information The online version contains supplementary material available at https://doi.org/10.1007/ s10530-021-02611-7

C. Romeo $\cdot$ N. Ferrari

Department of Veterinary Medicine, Università degli

Studi di Milano, Via dell'Università 6, 26900 Lodi, Italy

A. P. Piscitelli

Department of Biology, Evolutionary Ecology Group, University of Antwerp, Universiteitsplein 1, 2610 Wilrijk, Belgium

F. Santicchia · A. Martinoli $\cdot$ L. A. Wauters $(\bowtie)$ Department of Theoretical and Applied Sciences, Environment Analysis and Management Unit - Guido Tosi Research Group, Università degli Studi dell'Insubria, Via J. H. Dunant 3, 21100 Varese, Italy e-mail: lucas.wauters@uninsubria.it

N. Ferrari

Centro di Ricerca Coordinata Epidemiologia e Sorveglianza Molecolare delle Infezioni (EPISOMI), Università degli Studi di Milano, Milano, Italy through resource competition, and, only in the United Kingdom and Ireland, by competition mediated by a viral disease. In Italy such disease is absent, but spillover of an introduced North American nematode (Strongyloides robustus) from grey to red squirrels is known to occur. Here, we used long-term (9 years) capture-mark-recapture and parasitological data of red squirrels in areas co-inhabited by grey squirrels in Northern Italy to investigate the impact of this alien helminth on naïve native squirrels' body mass, local survival, and reproduction of females. We found no negative effect of the alien parasite on body mass or reproductive success, but intensity of infection by $S$. robustus reduced survival of both male and female squirrels. Significantly, survival of squirrels co-infected by their native nematode, Trypanoxyuris sciuri, was less affected by $S$. robustus, suggesting a protective effect of the native helminth against the new infection. Hence, we demonstrate that alien $S$. robustus spillover adds to the detrimental effects of resource competition and stress induced by grey squirrels, further reducing the fitness of the native species in the presence of the invasive competitor.

Keywords Invasive alien species - Strongyloides robustus · Sciurus vulgaris · Macroparasites · Parasite mediated competition · Tree squirrels 


\section{Introduction}

Biological invasions are considered one of the major threats to wildlife conservation (Clavero and GarcíaBerthou 2005; Vilà et al. 2010; Simberloff 2011). Once Invasive alien species (IAS) are introduced, they can threaten native species through several ecological processes, including competition, predation and hybridization (Largiadèr 2008; Doherty et al. 2016; Mazzamuto et al. 2017a). Furthermore, during the last decade, a number of studies have highlighted that parasites might play a paramount role in mediating invasions (Dunn et al. 2012; Strauss et al. 2012; Miller et al. 2018). For example, according to the "enemyrelease hypothesis", the higher demographic success of invaders may be partly due to the loss of many of their (co-evolved) parasites during the introduction process (Torchin et al. 2001; Prenter et al. 2004; Schoeman et al. 2019; Diagne et al. 2020; Gozzi et al. 2020). However, invading hosts will likely introduce at least some parasite species from their native range and these alien parasites may spill-over to a susceptible native species (Power and Mitchell 2004; Telfer and Bown 2012). It is widely assumed that such shared parasites may then mediate the competition between the two species: if the alien parasite has a greater impact on the naïve species than on the invader, the latter will gain a competitive advantage and the probability of a successful invasion will increase (disease-mediated invasions) (Strauss et al. 2012; McIntire and Juliano 2021). Finally, alien species may also acquire local parasites, amplifying (spillback: Kelly et al. 2009; Sherrard-Smith et al. 2015) or diluting their circulation (dilution effect: Thieltges et al. 2009; Telfer and Brown 2012).

One of the best-known paradigms of spillover and disease-mediated invasions is the Squirrel poxvirus (SQPV) which strongly influences the outcome of interspecific competition between introduced North American Eastern grey squirrels (Sciurus carolinensis) and native Eurasian red squirrels (S. vulgaris) in Great Britain and Ireland (Tompkins et al. 2002; Rushton et al. 2006). While several other examples of bacterial, viral or fungal infections spillover in the context of biological invasions have now been identified, studies demonstrating a detrimental effect of alien macroparasites on native vertebrate species are conversely surprisingly scarce (Lymbery et al. 2014). Still, we know that macroparasites can have a strong influence on hosts' fitness traits and consequently on population dynamics, affecting the outcome of interspecific competition to the point of causing the exclusion of one species by the other (Hudson and Greenman 1998; Greenman and Hudson 2000). For example, this was observed through experimental manipulation for the introduced ring-necked pheasant (Phasianus colchicus), the native grey partridge (Perdix perdix) and their shared parasite, Heterakis gallinarum in the U.K. (Tompkins et al. 2000, 2001). The paucity of evidence regarding alien macroparasite spillover might be partly due to the intrinsic difficulties of measuring their impact in native, often endangered, wildlife without recurring to experimental manipulation. An alternative approach to measure the usually sub-lethal effects of macroparisitic infection on free-living species is making use of long timeseries data that allow to highlight the impact of infection on fitness traits such as host survival, fecundity and body condition (Cattadori et al. 2008; Heins and Baker 2008; Leivesley et al. 2019).

Here we use therefore a long-time data series on red squirrels inhabiting areas colonised by introduced invasive grey squirrel to investigate the effects of an alien macroparasite spillover on body mass, local survival and reproduction in naive individuals of the native species. Since its introduction in Italy in 1948, in all sites colonised by the grey squirrel, red squirrel populations disappeared or are declining (Gurnell et al. 2004; Martinoli et al. 2010; Bertolino et al. 2014) due to interspecific competition for high-quality food resources which reduces female reproductive success and juvenile recruitment (Wauters et al. 2002a, 2002b; Gurnell et al. 2004). The effects of the alien species presence extend also to personality and physiology; in red-grey sites, red squirrels show higher sociability and higher concentration of stress hormones than in red-only sites (Santicchia et al. 2018a; Wauters et al. 2019). Contrary to Great Britain and Ireland, there is no evidence of SQPV circulating in Italy (Romeo et al. 2019), but spillover of an alien endoparasite (Strongyloides robustus) introduced by grey squirrels has been demonstrated (Romeo et al. 2015). In a natural situation (only red squirrels present), the gastrointestinal macroparasite fauna of red squirrels is dominated by a single nematode, Trypanoxyuris sciuri (prevalence $87.1 \%$ ) (Romeo et al. 2013). In contrast, grey squirrels in their native range co-evolved with a much richer macroparasite community and despite having 
lost many species during the introduction process, they successfully carried along the nematode $S$. robustus, which is the main helminth infecting Italian populations (prevalence 56.6\%) (Romeo et al. 2014a). In sites co-inhabited by the two species in Italy, grey squirrels acquire local $T$. sciuri from native red squirrels only rarely (Romeo et al. 2014a), whereas alien S. robustus frequently spills over to native squirrels reaching the same prevalence observed in the original host $(61 \%)$ (Romeo et al. 2015). In contrast with the known lethal effects of SQPV infection, the pathogenic effect of $S$. robustus on the native host species is still unknown, although Santicchia et al. (2020) showed that this infection in red squirrels reduces the host's expression of activity, an energetically costly personality trait.

It is known from experimental studies on laboratory rodents that the immune response against Strongyloides species ultimately hinders the worm's feeding capability, leading to adult parasites having a smaller size and a lower per capita reproductive output (Wilkes et al. 2004; Viney et al. 2006). Egg counts data coupled with adult worm intensity data (i.e. number of adult worms counted post-mortem within the intestine) suggest that a similar kind of response occurs also in the grey squirrel-S. robustus system (Romeo et al. 2014b). Lacking post-mortem data, we cannot say whether $S$. robustus infection in this naïve host elicits a similar, if any, specific immune response. However, a comparison of empirical data on egg counts in the two squirrel species suggests that red squirrels may not be able to effectively suppress $S$. robustus fecundity, as infected individuals shed on average over tenfold the eggs shed by grey squirrels, the natural hosts of $S$. robustus (Romeo et al. 2014b, 2020; Santicchia et al. 2020).

Using data from 9 years of capture-mark-recapture and parasitological data on red squirrels living in areas co-inhabited by grey squirrels, we tested for an effect of alien $S$. robustus spillover on naive native squirrels' condition and fitness. We predict that infection by the alien parasite ( $S$. robustus) will reduce the body condition of naïve red squirrels, measured as body mass (using foot length as a co-variate), and will negatively affect their fitness, either by reducing survival or reproduction. Finally, we expect animals co-infected by both the native and the alien parasite to suffer a greater decrease in body condition and/or fitness compared to mono-infected animals.

\section{Materials and methods}

Squirrel captures

Red squirrels were captured from 2011-2019 at six different sites located in Northern Italy, all coinhabited by alien grey squirrels at the time of trapping (Suppl. Material Table S1). All the sites are lowland mixed-deciduous woods (17-80 ha) characterised by similar tree-species composition [dominant tree species oaks (Quercus robur, Q. petraea, Q. rubra) and hornbeam (Carpinus betulus), with $<20 \%$ conifers] and climate. Squirrels were captured using Tomahawk live-traps (model 202, Tomahawk Live Trap Co., WI, USA) that were baited with hazelnuts and checked every three hours to limit containment stress. At first capture, each squirrel was marked with a numbered ear-tag (Monel 1005 1L1 ear-tag, National Band \& Tag Co. Newport, KY, USA) and sexed. At every trapping occasion, squirrels were weighed to the nearest $g$ using a spring balance, their right hind foot measured to the nearest $0.5 \mathrm{~mm}$ (nails excluded) with a thin wing ruler (Wauters et al. 2007; Mazzamuto et al. 2017b), and their reproductive condition recorded as described in (Dantzer et al. 2016). We considered a female as reproductively active when it was in post-oestrus, pregnant or lactating (Wauters and Lens 1995; Santicchia et al. 2018b). Tape tests for parasitological examination for T. sciuri were collected by sticking for a few seconds $3 \mathrm{~cm}$ of transparent adhesive tape (Scotch ${ }^{\mathrm{TM}}$ 508, $3 \mathrm{M}$ Company, USA) on a squirrel's perianal region and then applying the tape on a microscope slide. Slides were stored in a slide plastic holder to keep them spaced apart. Whole faecal pellets for copromicroscopic analysis of $S$. robustus were collected from the trap floor and the ground below and stored dry at $4{ }^{\circ} \mathrm{C}$ until laboratory analysis. The trap floor was cleaned with $90 \%$ alcohol after each capture and the ground below the trap was carefully brushed, to avoid cross-contamination among consecutive trappings.

\section{Parasitological examination}

Both tape tests and faecal samples were examined within 4 days from sampling, to prevent helminth eggs deterioration. Tape tests were examined under a microscope $(40 \times$ magnification $)$ for $T$. sciuri eggs to obtain qualitative information on infection status 
(i.e., infected or not-infected). Faecal samples were analysed through the quantitative McMaster method, by using saturated $\mathrm{NaCl}$ solution $(1200 \mathrm{~g} / \mathrm{l})$ as described in (Romeo et al., 2014b, 2015). Briefly, both chambers of a McMaster slide were filled with faeces diluted in a known volume of solution $(10 \mathrm{ml} / \mathrm{g}$ of faeces), the slide examined under a microscope $(100 \times$ magnification $)$ and helminth eggs identified and counted.

\section{Statistical analysis}

Since seasonal fluctuations in body mass as well as effects of reproductive condition on body mass differ between male and female red squirrels (Wauters and Dhondt 1989; Wauters et al. 2007) and reproductive success was determined only for females, we analysed the effects of parasite infection for each sex separately.

Individual variation in i) body mass ii) local survival over the next 12 months (yes/no) and iii) reproductive success of females during the breeding seasons (produced a litter yes/no) was investigated using linear mixed models (i) and mixed logistic regressions (ii and iii). The dependent variable local survival (model ii) from time ${ }_{\mathrm{t} 0}$ to time $\mathrm{t}_{12}$ was scored 1 if an individual was still present in the study area 12 months after the initial capture (time $\mathrm{t}_{\mathrm{t}}$ ), it was scored 0 when it was no longer present at time $\mathrm{t}_{\mathrm{t} 2 \text {. }}$ (see also Wauters et al. 2007 and Santicchia et al. 2018b). Juvenile squirrels $(<260 \mathrm{~g})$ were excluded from the analyses. Year 2019 was excluded from survival (ii) models since we had no recapture data for 2020 (12 months later), while captures from non-breeding months (i.e. November, December and January) were excluded from the female reproductive success (iii) model. In all models, year was added as a random intercept and individual IDs were included as a repeated measure with a compound symmetry covariance structure to account for pseudoreplication (Verbeke and Molenberghs 2000). The effect of parasite infection on the three dependent variables was explored by including as explanatory variables: $S$. robustus faecal egg counts (SrFEC, the number of eggs counted in a McMaster slide), presence/absence of $T$. sciuri (TsPA), presence/absence of other helminths (otherPA), and a first order SrFEC*TsPA interaction. Highly skewed SrFEC data were logtransformed $[\ln (x+1)]$ to improve the fit of the models. We further tested for the effect of foot length (model i), season/breeding season (i and iii), study area (all models) and reproductive condition (i and ii). We started from full models and obtained minimal models through backward elimination of non-significant variables and interactions (partial $\mathrm{p}$ set at 0.15 ; Supplementary material Tables S2 to S6). Comparisons of factors with more than two levels was carried out through t-tests on differences of least square means, applying Tukey's correction for multiple comparisons. Unless otherwise indicated, all values are represented as mean \pm Standard Error (SE). All the analysis were carried out using PROC GLIMMIX in SAS 9.4 software (Copyright (C) 2012 SAS Institute Inc., Cary, NC, USA).

\section{Results}

Parasitological examination

We collected data from 166 different adult red squirrels (88 males and 78 females), for a total of 366 examined parasitological samples (193 from males and 173 from females). Overall, 210 samples were positive for S. robustus $(57.4 \%$; 95\%CI: $52.3 \%-$ $62.5 \%), 280$ samples were positive for $T$. sciuri $(76.5 \% ; 72.1 \%-80.9 \%)$ and only 32 samples $(8.7 \%$; $5.8 \%-11.6 \%$ ) were positive for other gastro-intestinal helminth taxa (namely strongylid and capillarid nematodes). Roughly half of the samples (44.8\%; $39.7 \%-49.9)$ showed S. robustus and T. sciuri coinfection. Mean abundance of $S$. robustus eggs in red squirrel's faeces was $5204 \pm 772$ EPG (eggs/gram of faeces), with values in infected individuals ranging from 33 to over 160.000 EPG. Detailed results of parasitological examination by sex are provided in Table 1.

\section{Male squirrels}

Body mass ( $\mathrm{g}$ ) of male red squirrels varied positively with SrFEC (parameter estimate \pm SE: $7.2 \pm 2.0$; $p=0.0003)$ and hind foot length $(8.3 \pm 1.8$; $p<0.0001)$. It varied also by study area $(p=0.034)$, was higher in reproductively active males (i.e., males with scrotal testes; $p=0.0006$ ) and in autumn and winter than in spring $\left(p_{\text {adj }}<0.0001\right.$ and $p_{\text {adj }}=0.0011$, respectively; Table S2). 
Table 1 Infection by native (Trypanoxyuris sciuri) and alien (Strongyloides robustus) gastro-intestinal helminths in 166 red squirrels (Sciurus vulgaris) co-inhabiting with alien grey squirrels (S. carolinensis). $\mathrm{N}=\mathrm{nr}$. of examined samples, $\mathrm{P}=$ prevalence of infection $(\%), \mathrm{EPG}=$ no. of eggs/gram of faeces

\begin{tabular}{lllllll}
\hline & $\mathrm{N}$ & $\begin{array}{l}\text { S. robustus } \mathrm{P} \\
(95 \% \mathrm{CI})\end{array}$ & $\begin{array}{l}\text { T. sciuri } \mathrm{P} \\
(95 \% \mathrm{CI})\end{array}$ & $\begin{array}{l}\text { Other taxa P } \\
(95 \% \mathrm{CI})\end{array}$ & $\begin{array}{l}\text { S. robustus-T. sciuri co-infection } \\
\mathrm{P}(95 \% \mathrm{CI})\end{array}$ & $\begin{array}{l}\text { S. robustus EPG } \\
(\mathrm{mean} \pm \mathrm{SE})\end{array}$ \\
\hline Females & 173 & 59.5 & 76.9 & 8.1 & 46.8 & $5,482 \pm 1,241$ \\
& & $(52.1-66.9)$ & $(70.5-83.2)$ & $(4.0-12.2)$ & $(39.3-54.3)$ & $4,955 \pm 955$ \\
Males & 193 & 55.4 & 76.2 & 9.3 & 43.0 & $5,204 \pm 772$ \\
& & $(48.4-62.5)$ & $(70.1-82.2)$ & $(5.2-13.5)$ & $(35.9-50.5)$ & 44.8 \\
\multirow{2}{*}{ Total } & 366 & 57.4 & 76.5 & 8.7 & $(39.7-49.9)$ & \\
& $(52.3-62.5)$ & $(72.1-80.9)$ & $(5.8-11.6)$ & \\
\hline
\end{tabular}

The probability for male squirrels of surviving over the next 12 months was negatively associated with both SrFEC $(-0.22 \pm 0.21 ; p=0.0042)$ and TsPA ($1.23 \pm 0.58 ; \mathrm{p}=0.034)$. Additionally, there was a significant interaction between the two parasites $(\mathrm{p}=0.047)$, with a stronger negative effect of SrFEC on survival in animals not coinfected by $T$. sciuri (Fig. 1a; Table S3).

Female squirrels

Body mass ( $\mathrm{g}$ ) of female red squirrels varied positively with hind foot length (parameter estimate $\pm \mathrm{SE}$ :
$10.33 \pm 1.61 ; p<0.0001)$ and was associated with reproductive conditions $(p<0.0001)$, with nonbreeding females showing lower values than both post-oestrus and lactating females (both $p_{\text {adj- }}$ $<0.0001$; Table S4).

The probability for female squirrels of surviving over the next 12 months was negatively associated with both SrFEC $(-0.20 \pm 0.23 ; p=0.036)$ and TsPA $(-1.88 \pm 0.61 ; p=0.0021)$ (Fig. 1b). The final model (Table S5) retained the SrFEC*TsPA interaction where it showed the same pattern found for males, but was not significant ( $p=0.11$ ), and a non-significant effect of body mass $(p=0.070)$.
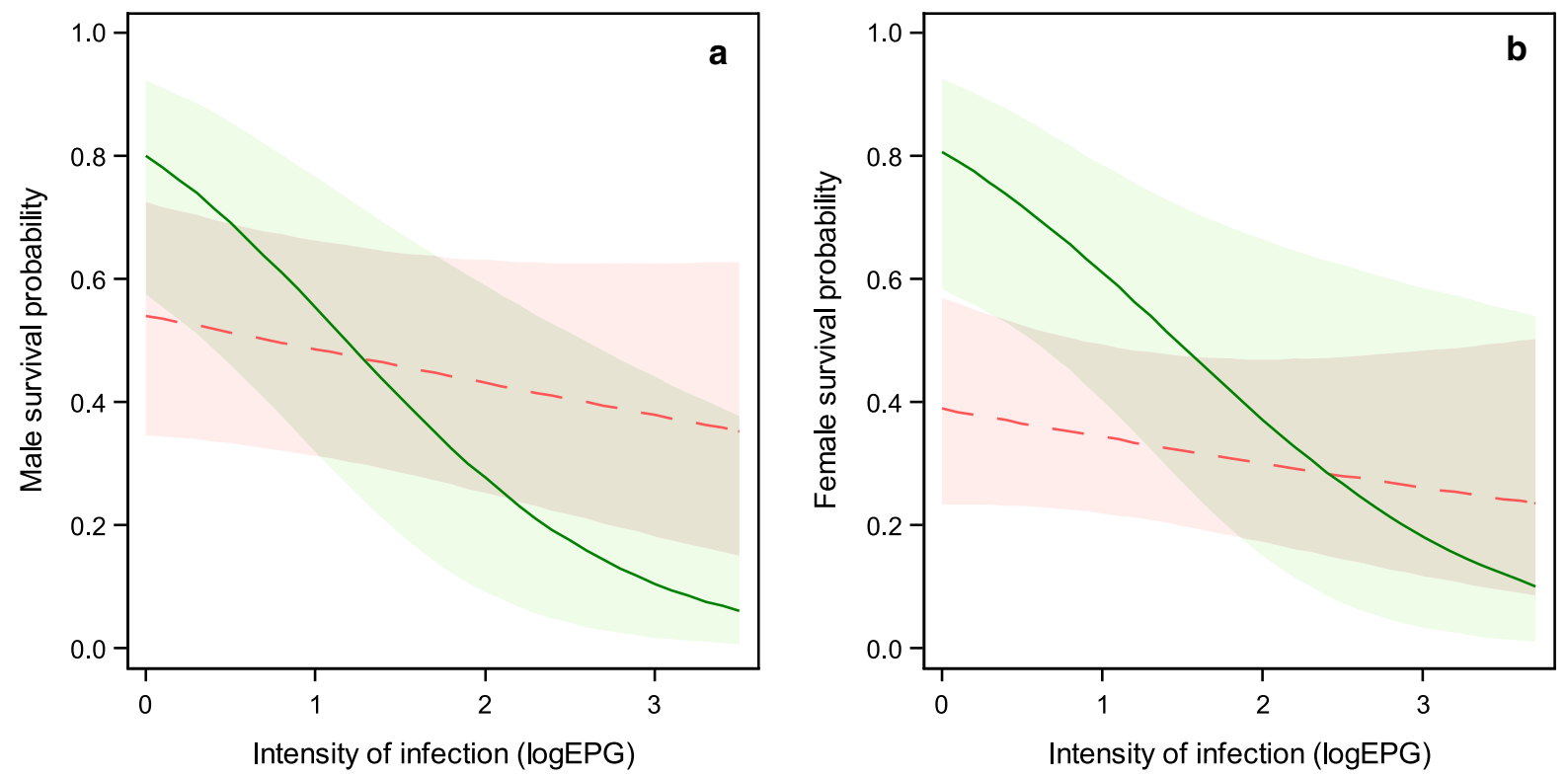

Fig. 1 Predicted relationship between survival probability and S. robustus fecal egg counts (log-transformed values) in (a) male red squirrels and (b) female red squirrels coinfected (red) and not coinfected (green) by T. sciuri. Bands represent $90 \%$ confidence limits 
Finally, reproductive success of females was positively influenced by body mass $(0.09 \pm 0.02$; $p<0.0001$ ) and varied between the two breeding seasons, with a higher probability of reproducing successfully in spring than in autumn $(p<0.0001)$. There was also a significant difference among study areas $(p=0.046)$, while the effect of SrFEC was not significant ( $p=0.08$; Table S6).

\section{Discussion}

We investigated the effects of infection by alien $S$. robustus and native $T$. sciuri nematodes on body mass, local survival and reproduction of native red squirrels. As predicted, intensity of infection by $S$. robustus (measured as faecal egg counts) had a general negative effect on survival of both male and female red squirrels. However, there was no effect of the alien parasite on female squirrels' reproductive success or body mass, whereas in males we found a positive relationship between body mass and $S$. robustus egg counts. Infection by $T$. sciuri had a negative effect on squirrels' survival as well, while consistently with previous findings (e.g., Romeo et al. 2013, 2015) other gastro-intestinal parasite species were found rarely and did not affect any of the examined variables.

Our data showed that in squirrels of both sexes, the probability of surviving over the next twelve months was negatively related to $S$. robustus egg counts, indicating a negative effect of the alien parasite on local red squirrel survival. It is widely assumed that spillover of an alien parasite from an invading to a closely-related native species will be severely detrimental to the new host, because the naïve species will represent a physiologically similar host, but lack any coevolved tolerance or resistance to the parasite (Prenter et al. 2004; Strauss et al. 2012; McIntire and Juliano 2021). However, despite such host-switching events appear to be relatively common in biological invasions, studies demonstrating the pathogenic effect of alien macroparasites on native animal hosts, particularly mammals, are surprisingly few and only in a handful of cases the impact on naïve hosts was found to be higher than on the natural host, supporting the occurrence of parasite-mediated competition (see Lymbery et al. 2014 and references therein). This is at least partially related to the intrinsic challenges of quantifying macroparasitic impacts in living, often threatened, animal species. Except for a few observational data on $S$. robustus severe infections (Davidson 1976), the impact of this parasite on grey squirrel fitness is still unknown, hence we cannot say whether the nematode has a greater impact on its natural or new host species. However, we had demonstrated in a previous work that infection by alien $S$. robustus reduces costly personality traits in red squirrels (Santicchia et al. 2020), and here we further show that the parasite has a negative impact on the native species survival. We acknowledge that our local survival estimate is influenced by recapture probability and potential dispersal (emigration) of marked animals, but since both annual recapture probabilities and site-fidelity of adult red squirrels are high (for detailed analyses and discussion see Wauters et al. 2004, 2008 and Santicchia et al. 2018b), we are confident that our estimate mostly captures actual survival rather than dispersal. A different source of bias in annual survival estimates could be due to the parasite affecting host behaviour and/or its willingness to enter a trap, measured as trappability (Santicchia et al. 2018b, 2021). As mentioned above, we indeed found that infection by alien $S$. robustus reduced host activity, an energetically costly personality trait (Santicchia et al. 2020). However, since individual variation in levels of activity in the red squirrel is not correlated with the animals' trappability (Santicchia et al. 2021), and since average annual capture probabilities in the populations studied here were high (ca. 90\%), we are confident that our survival estimates are not biased in relation to intensity of infection. Hence, independently from its potential role in mediating the competition between the two squirrels, we can affirm that $S$. robustus spillover surely adds to the detrimental effects induced by the presence of invasive alien grey squirrels on physiological stress in co-occurring red squirrels (Santicchia et al. 2018a), and on interspecific resource competition, which reduces red squirrel fitness (Gurnell et al. 2004). Reduced survival of native red squirrels was also observed in areas invaded by another alien competitor, Callosciurus erythraeus (Mazzamuto et al. 2017a), although in this system there was no evidence of spillover of macroparasites (Mazzamuto et al. 2016), but red squirrels had a poorer body condition when cooccurring with the IAS (Mazzamuto et al. 2017b).

In addition to $S$. robustus, our data show that red squirrels infected by native $T$. sciuri had a reduced 
survival probability compared to uninfected individuals. Contrary to our expectations however, coinfection by these two parasites did not result in the lowest survival probability. On the contrary, in male squirrels, the negative effect of the alien parasite was significantly stronger in individuals that were not coinfected by the native parasite, and a similar tendency was detected in females, albeit not significant. The observed interaction however, depends on S. robustus intensity of infection: as expected, at low EPG values mono-infected animals showed a higher survival probability compared to co-infected individuals, but the pattern reversed after a certain infection threshold. This suggests that $T$. sciuri infection has a protective effect from $S$. robustus, either by reducing its virulence through inter-specific competition or by increasing the host resistance or tolerance against it through immune-mediated effects (Cox 2001; Lello et al. 2004; Karvonen et al. 2019). Although egg counts (for $S$. robustus) and presence/absence data (for $T$. sciuri) do not allow us to draw any conclusion on this, a strong competitive interaction between the two parasite species appears unlikely, since they exploit different niches within a squirrel's gastro-intestinal tract (Anderson 2000). Hence, this result might be instead related to cross-immunity, with co-infected squirrels benefitting from the immune response already mounted against the native parasite (Cox 2001; Karvonen et al. 2019). Alternatively, infection by alien $S$. robustus in naïve individuals might lead to immunopathology (Graham et al. 2005) and in this case, a previous exposure to $T$. sciuri could have a protective effect by modulating the immune response and inhibiting severe inflammation, as observed in other systems (Bazzone et al. 2008). Independently from co-infection, our results show that alien $S$. robustus has a consistent negative effect on survival in red squirrels of both sexes: the higher the egg count, the lower the probability to survive over the next twelve months.

Using body mass itself as a condition index, contrary to our predictions we observed a positive relationship between $S$. robustus egg counts and squirrels body mass in males, but not in females. Adding foot length as a co-variate in our models allowed to partially correct for the confounding effect of size on body mass, but we are aware that body mass represents at best a coarse index of body condition that, while being able to reveal some macroecological patterns, cannot reflect the finer and subtle effects of a macroparasitic infection. Hence, this positive relationship between parasitic infection and body mass is probably an indirect consequence of other mechanisms that might influence exposure, like dominance and social structure. Indeed, earlier studies revealed that also T. sciuri abundance (adult helminth counts in the intestine of road-killed individuals) increased with host body mass in male red squirrels, but decreased in females (Romeo et al. 2013). Moreover, in its native host, the grey squirrel, $S$. robustus abundance (adult worm counts) was positively related with squirrel body mass as well, in this case independent of sex (Romeo et al. 2014a). The other relationships of body mass with foot length, season, and reproductive condition confirmed patterns discussed in detail in earlier studies (Wauters and Dhondt 1989; Wauters et al. 2007).

As in previous studies, female reproductive success strongly depended on body mass and varied with season and among study areas (Wauters and Dhondt 1989; Wauters and Lens 1995; Wauters et al. 2007), but it was not affected by any of our measures of parasite infection. Theoretical models predict that highly prevalent parasites affecting host fecundity may have a dramatic impact on population dynamics, quickly leading small populations to extinction (McCallum and Dobson 1995; O'Keefe and Antonovics 2002). In the light of this, the lack of any relationship between $S$. robustus and female red squirrel reproductive success appears reassuring. However, post-breeding data on litter size would be needed to truly exclude a parasite-mediated reduction on females' reproductive output. Earlier studies showed also that local recruitment of juvenile red squirrels was also strongly reduced where the native species co-occurred with the alien congener (Gurnell et al. 2004). In the present study we did not investigate effects of $S$. robustus spillover on the recruitment (early survival) of red squirrels, because monitoring juvenile survival and settlement requires a different approach of intensive capture-mark-recapture and radio-tracking (Wauters et al. 1993, 2010). Future studies monitoring parasite infection, movement, dispersal and settlement of juveniles and subadults would be paramount to explore potential effects of spillover during early life.

Overall, our results demonstrate that spillover of an alien macroparasite, co-introduced with its invasive 
host, reduces survival in a native mammal, further adding to the detrimental effects on its fitness induced by other forms of competitive interactions with the invasive host species. This finding highlights the importance of taking into account macroparasitic infections when dealing with biological invasions, as their subtle effects on fitness are indeed often overlooked, yet may contribute to drive native species to extinction. Further data on reproductive output coupled with a mathematical modelling approach could disclose the impact of $S$. robustus spillover on red squirrel population dynamics, while investigating the pathogenicity of the same parasite on its grey squirrel natural host would reveal whether this endoparasite is actually mediating the competition between the two squirrel species.

Acknowledgements We thank Regione Lombardia, Città Metropolitana di Torino, natural reserve 'Bosco WWF di Vanzago' and the owners of private estates for permits and access to the study sites. We also thank Mattia Panzeri and dedicated thesis students for helping with data collection.

Authors contribution C.R. analysed samples, performed statistical analysis, conceptualized the project and co-wrote the first draft and worked on revisions of the manuscript. A.P.P. conducted fieldwork, analysed samples, co-wrote the first draft and worked on revisions of the manuscript. F.S. conducted fieldwork, analysed samples and assisted with production and revisions of the manuscript. A.M. attained permits funding, assisted with the fieldwork and assisted with production and revisions of the manuscript. N.F. conceptualized the project, attained funding and assisted with production and revisions of the manuscript. L.A.W. conceptualized the project, conducted fieldwork, assisted with statistical analysis, and worked on revisions of the manuscript.

Funding Open access funding provided by Università degli Studi dell'Insubria within the CRUI-CARE Agreement. No funding was received for conducting this study.

Data Availability All data generated or analysed during this study are included in this published article [and its supplementary information files].

Code availability All SAS scripts used in model analysis are available in the Supplementary Information files.

\section{Declarations}

Conflict of interest The authors declare that they have no conflict of interest.

Consent to participate All authors have given their consent to participate.
Consent for publication All authors have given their consent for publication of this paper upon acceptance.

Ethics approval Animal welfare note: We used free-living animals from wild populations. Our procedures of trapping, handling and marking squirrels complied with the Guidelines for the treatment of animals in behavioural research and teaching (Animal Behaviour, 2020, 159, I-XI; https://doi.org/ 10.1016/j.anbehav.2019.11.002). We partly covered the Tomahawk Live Traps (Model 202, Tomahawk Live Trap Co., Hazelhurst, WI, USA) with dark plastic bag to provide animals with shelter, and checked traps three times/day to minimize time in trap. Before handling, we completely covered the trap with a cloth to reduce stress. We flushed the trapped animal in a zippertube handling bag to reduce direct contact with the operator. At first capture, we marked each squirrel with a Monel 1005 1L1 ear-tag (size $2.3-10 \mathrm{~mm}, 0.2 \mathrm{~g}$ or less than $0.1 \%$ of squirrel's body mass; National Band \& Tag Co. Newport, KY, USA), putting the tag near the base of the ear to reduce risk of injury. There is no evidence that ear-tags affect grooming behaviour or occurrence of ectoparasite around the ear region. To reduce stress, only trained researchers handled the squirrels, and handling time was kept as short as possible $(<5 \mathrm{~min})$. The animals were released at the trap site immediately after handling. Since the study was part of long-term population dynamics research project, that aimed at estimating population size based on CMR, all animals captured were marked (no sample size restrictions). Trapping and handling squirrels complied with the current laws on animal research in Italy (legal requirements according to the Italian Wildlife Protection and Hunting Law L.N. 157 from 1992, and scientific guidelines from the Italian Institute for Environmental Protection and Research, ISPRA) and were carried out under permissions of the authorities for wildlife research and management of Lombardy Region, the province of Cuneo, and the province/città metropolitana of Turin. Fieldwork was approved by authorizations N. 180-14616 of 06/07/2011, N. 294-34626 of 12/09/2014 from the Provincia di Torino and N. 62-3025 (2017-2019) from the Città Metropolitana di Torino; Protocol N.0046790 of 06/07/2011 and N. 0002624 of 13/01/2014 from the province of Cuneo; and decrees N. 1702 (23/02/2009), N. $11190(29 / 11 / 2013)$, N. 9523 (15/10/2014) and N. 198 (13/01/2017) from Direzione Generale Agricoltura, Regione Lombardia, Italy. (include appropriate approvals or waivers).

Open Access This article is licensed under a Creative Commons Attribution 4.0 International License, which permits use, sharing, adaptation, distribution and reproduction in any medium or format, as long as you give appropriate credit to the original author(s) and the source, provide a link to the Creative Commons licence, and indicate if changes were made. The images or other third party material in this article are included in the article's Creative Commons licence, unless indicated otherwise in a credit line to the material. If material is not included in the article's Creative Commons licence and your intended use is not permitted by statutory regulation or exceeds the permitted use, you will need to obtain permission directly from the copyright holder. To view a copy of this licence, visit http://creativecommons.org/licenses/by/4.0/. 


\section{References}

Anderson RC (2000) Nematode parasites of vertebrates: their development and transmission. CABI, Wallingford

Bazzone LE, Smith PM, Rutitzky LI, Shainheit MG, Urban JF, Setiawan T, Blum AM, Weinstock JV, Stadecker MJ (2008) Coinfection with the Intestinal Nematode Heligmosomoides polygyrus Markedly Reduces Hepatic EggInduced Immunopathology and Proinflammatory Cytokines in Mouse Models of Severe Schistosomiasis. Infect Immun 76:5164-5172. https://doi.org/10.1128/IAI.0067308

Bertolino S, Di Montezemolo NC, Preatoni DG, Wauters LA, Martinoli A (2014) A grey future for Europe: Sciurus carolinensis is replacing native red squirrels in Italy. Biol Invasions 16:53-62. https://doi.org/10.1007/s10530-0130502-3

Cattadori IM, Boag B, Hudson PJ (2008) Parasite co-infection and interaction as drivers of host heterogeneity. Int J Parasitol 38:371-380. https://doi.org/10.1016/j.ijpara.2007. 08.004

Clavero M, García-Berthou E (2005) Invasive species are a leading cause of animal extinctions. Trends Ecol Evol 20:110. https://doi.org/10.1016/j.tree.2005.01.003

Cox FEG (2001) Concomitant infections, parasites and immune responses. Parasitol 122:S23-S38. https://doi.org/10.1017/ S003118200001698X

Dantzer B, Santicchia F, van Kesteren F, Palme R, Martinoli A, Wauters LA (2016) Measurement of fecal glucocorticoid metabolite levels in Eurasian red squirrels (Sciurus vulgaris): effects of captivity, sex, reproductive condition, and season. J Mammal 97:1385-1398. https://doi.org/10.1093/ jmammal/gyw095

Davidson WR (1976) Endoparasites of Selected Populations of gray squirrels (Sciurus carolinensis) in the Southeastern United States. Proc Helm Soc Wash 43:211-217

Diagne C, Granjon L, Gueye MS, Ndiaye A, Kane M, Niang Y, Tatard C, Brouat C (2020) Association between temporal patterns in helminth assemblages and successful range expansion of exotic Mus musculus domesticus in Senegal. Biol Invasions 22:3003-3016. https://doi.org/10.1007/ s10530-020-02304-7

Doherty TS, Glen AS, Nimmo DG, Ritchie EG, Dickman CR (2016) Invasive predators and global biodiversity loss. Proc Natl Acad Sci 113:11261-11265. https://doi.org/10. 1073/pnas.1602480113

Dunn AM, Torchin ME, Hatcher MJ, Kotanen PM, Blumenthal DM, Byers JE, Coon CAC, Frankel VM, Holt RD, Hufbauer RA, Kanarek AR, Schierenbeck KA, Wolfe LM, Perkins SE (2012) Indirect effects of parasites in invasions. Funct Ecol 26:1262-1274. https://doi.org/10.1111/j.13652435.2012.02041.x

Gozzi AC, Lareschi M, Navone GT, Guichón ML (2020) The enemy release hypothesis and Callosciurus erythraeus in Argentina: combining community and biogeographical parasitological studies. Biol Invasions 22:3519-3531. https://doi.org/10.1007/s10530-020-02339-w

Graham AL, Allen JE, Read AF (2005) Evolutionary Causes and Consequences of Immunopathology. Annu Rev Ecol Evol
Syst 36:373-397. https://doi.org/10.1146/annurev.ecolsys. 36.102003.152622

Greenman JV, Hudson PJ (2000) Parasite-mediated and direct competition in a two-host shared macroparasite system. Theor Popul Biol 57:13-34. https://doi.org/10.1006/tpbi. 1999.1435

Gurnell J, Wauters LA, Lurz PWW, Tosi G (2004) Alien species and interspecific competition: effects of introduced eastern grey squirrels on red squirrel population dynamics. J Anim Ecol 73:26-35. https://doi.org/10.1111/j.1365-2656.2004. 00791.x

Heins D, Baker J (2008) The stickleback-Schistocephalus hostparasite system as a model for understanding the effect of a macroparasite on host reproduction. Behaviour 145:625-645. https://doi.org/10.1163/ 156853908792451412

Hudson P, Greenman J (1998) Competition mediated by parasites: biological and theoretical progress. Trends Ecol Evol 13:387-390. 5347(98)01475-X

Karvonen A, Jokela J, Laine AL (2019) Importance of sequence and timing in parasite coinfections. Trends Parasitol 35:109-118. https://doi.org/10.1016/j.pt.2018.11.007

Largiadèr CR (2008) Hybridization and introgression between native and alien species. Biological Invasions. Springer, Berlin, Heidelberg, pp 275-292

Leivesley JA, Bussière LF, Pemberton JM, Pilkington JG, Wilson K, Hayward AD (2019) Survival costs of reproduction are mediated by parasite infection in wild Soay sheep. Ecol Lett 22:1203-1213. https://doi.org/10.1111/ ele. 13275

Lello J, Boag B, Fenton A, Stevenson IR, Hudson PJ (2004) Competition and mutualism among the gut helminths of a mammalian host. Nature 428:840-844. https://doi.org/10. 1038/nature02490

Lymbery AJ, Morine M, Kanani HG, Beatty SJ, Morgan DL (2014) Co-invaders: the effects of alien parasites on native hosts. Int J Parasitol Parasites Wildl 3:171-177. https://doi. org/10.1016/j.ijppaw.2014.04.002

Martinoli A, Bertolino S, Preatoni DG, Balduzzi A, Marsan A, Genovesi P, Tosi G, Wauters LA (2010) Headcount 2010: the multiplication of the grey squirrel populations introduced to Italy. Hystrix Ital J Mammal 21:127-136. https:// doi.org/10.4404/hystrix-21.2-4463

Mazzamuto MV, Pisanu B, Romeo C, Ferrari N, Preatoni D, Wauters LA, Chapuis JL, Martinoli A (2016) Poor parasite community of an invasive alien species: macroparasites of Pallas's squirrel in Italy. Ann Zool Fenn 53:103-112. https://doi.org/10.5735/086.053.0209

Mazzamuto MV, Bisi F, Wauters LA, Preatoni DG, Martinoli A (2017a) Interspecific competition between alien Pallas's squirrels and Eurasian red squirrels reduces density of the native species. Biol Invasions 19:723-735. https://doi.org/ 10.1007/s10530-016-1310-3

Mazzamuto MV, Morandini M, Panzeri M, Wauters LA, Preatoni DG, Martinoli A (2017b) Space invaders: effects of invasive alien Pallas's squirrel on home range and body mass of native red squirrel. Biol Invasions 19:1863-1877. https://doi.org/10.1007/s10530-017-1396-2

McCallum H, Dobson A (1995) Detecting disease and parasite threats to endangered species and ecosystems. Trends Ecol 
Evol 10:190-194. https://doi.org/10.1016/S01695347(00)89050-3

McIntire KM, Juliano SA (2021) Detrimental effects of a failed infection by a co-invasive parasite on a native congeneric parasite and its native host. Biol Invasions. https://doi.org/ 10.1007/s10530-021-02464-0

Miller MA, Kinsella JM, Snow RW, Hayes MM, Falk BG, Reed RN, Mazzotti FJ, Guyer C, Romagosa CM (2018) Parasite spillover: indirect effects of invasive Burmese pythons. Ecol Evol 8:830-840. https://doi.org/10.1002/ece3.3557

O'Keefe KJ, Antonovics J (2002) Playing by different rules: the evolution of virulence in sterilizing pathogens. Am Nat 159:597-605. https://doi.org/10.1086/339990

Power AG, Mitchell CE (2004) Pathogen spillover in disease epidemics. Am Nat 164:S79-S89. https://doi.org/10.1086/ 424610

Prenter J, MacNeil C, Dick JTA, Dunn AM (2004) Roles of parasites in animal invasions. Trends Ecol Evol 19:385-390. https://doi.org/10.1016/j.tree.2004.05.002

Romeo C, Pisanu B, Ferrari N, Basset F, Tillon L, Wauters LA, Martinoli A, Saino N, Chapuis JL (2013) Macroparasite community of the Eurasian red squirrel (Sciurus vulgaris): poor species richness and diversity. Parasitol Res 112:3527-3536. https://doi.org/10.1007/s00436-0133535-8

Romeo C, Wauters LA, Ferrari N, Lanfranchi P, Martinoli A, Pisanu B, Preatoni DG, Saino N (2014a) Macroparasite fauna of alien grey squirrels (Sciurus carolinensis): composition, variability and implications for native species. PLoS ONE 9:e88002. https://doi.org/10.1371/journal. pone. 0088002

Romeo C, Wauters LA, Cauchie S, Martinoli A, Matthysen E, Saino N, Ferrari N (2014b) Faecal egg counts from field experiment reveal density dependence in helminth fecundity: Strongyloides robustus infecting grey squirrels (Sciurus carolinensis). Parasitol Res 113:3403-3408. https:// doi.org/10.1007/s00436-014-4005-7

Romeo C, Ferrari N, Lanfranchi P, Saino N, Santicchia F, Martinoli A, Wauters LA (2015) Biodiversity threats from outside to inside: effects of alien grey squirrel (Sciurus carolinensis) on helminth community of native red squirrel (Sciurus vulgaris). Parasitol Res 114:2621-2628. https:// doi.org/10.1007/s00436-015-4466-3

Romeo C, McInnes CJ, Dale TD, Shuttleworth C, Bertolino S, Wauters LA, Ferrari N (2019) Disease, invasions and conservation: no evidence of squirrelpox virus in grey squirrels introduced to Italy. Anim Conserv 22:14-23. https://doi.org/10.1111/acv.12433

Romeo C, Wauters LA, Santicchia F, Dantzer B, Palme R, Martinoli A, Ferrari N (2020) Complex relationships between physiological stress and endoparasite infections in natural populations. Curr Zool 66:449-457. https://doi.org/ 10.1093/cz/zoaa029

Rushton SP, Lurz PWW, Gurnell J, Nettleton P, Bruemmer C, Shirley MDF, Sainsbury AW (2006) Disease threats posed by alien species: the role of a poxvirus in the decline of the native red squirrel in Britain. Epidemiol Infect 134:521-533. https://doi.org/10.1017/ S0950268805005303

Santicchia F, Dantzer B, van Kesteren F, Palme R, Martinoli A, Ferrari N, Wauters LA (2018a) Stress in biological invasions: Introduced invasive grey squirrels increase physiological stress in native Eurasian red squirrels. J Anim Ecol 87:1342-1352. https://doi.org/10.1111/13652656.12853

Santicchia F, Gagnaison C, Bisi F, Martinoli A, Matthysen E, Bertolino S, Wauters LA (2018b) Habitat-dependent effects of personality on survival and reproduction in red squirrels. Behav Ecol Sociobiol 72:1-13. https://doi.org/ 10.1007/s00265-018-2546-y

Santicchia F, Wauters LA, Piscitelli AP, Dongen SV, Martinoli A, Preatoni D, Romeo C, Ferrari N (2020) Spillover of an alien parasite reduces expression of costly behaviour in native host species. J Anim Ecol 89:1559-1569. https://doi. org/10.1111/1365-2656.13219

Santicchia F, Van Dongen S, Martinoli A, Preatoni D, Wauters LA (2021) Measuring personality traits in Eurasian red squirrels: a critical comparison of different methods. Ethology 127:187-201. https://doi.org/10.1111/eth.13117

Schoeman AL, Kruger N, Secondi J, du Preez LH (2019) Repeated reduction in parasite diversity in invasive populations of Xenopus laevis: a global experiment in enemy release. Biol Invasions 21:1323-1338. https://doi.org/10. 1007/s10530-018-1902-1

Sherrard-Smith E, Chadwick EA, Cable J (2015) The impact of introduced hosts on parasite transmission: opisthorchiid infections in American mink (Neovison vison). Biol Invasions 17:115-122. https://doi.org/10.1007/s10530-0140709-y

Simberloff D (2011) How common are invasion-induced ecosystem impacts? Biol. Invasions 13:1255-1268. https:// doi.org/10.1007/s10530-011-9956-3

Strauss A, White A, Boots M (2012) Invading with biological weapons: the importance of disease-mediated invasions. Funct Ecol 26:1249-1261. https://doi.org/10.1111/13652435.12011

Telfer S, Bown K (2012) The effects of invasion on parasite dynamics and communities. Funct Ecol 26:1288-1299. https://doi.org/10.1111/j.1365-2435.2012.02049.x

Thieltges DW, Reise K, Prinz K, Jensen KT (2009) Invaders interfere with native parasite-host interactions. Biol Invasions 11:1421-1429. https://doi.org/10.1007/s10530-0089350-y

Tompkins DM, Greenman JV, Robertson PA, Hudson PJ (2000) The role of shared parasites in the exclusion of wildlife hosts: Heterakis gallinarum in the ring-necked pheasant and the grey partridge. J Anim Ecol 69:829-840. https:// doi.org/10.1046/j.1365-2656.2000.00439.x

Tompkins DM, Greenman J, Hudson PJ (2001) Differential impact of a shared nematode parasite on two gamebird hosts: implications for apparent competition. Parasitology 122:187-193. https://doi.org/10.1017/ S0031182001007247

Tompkins DM, Sainsbury AW, Nettleton P, Buxton D, Gurnell J (2002) Parapoxvirus causes a deleterious disease in red squirrels associated with UK population declines. Proc R Soc Lond B Biol Sci 269:529-533. https://doi.org/10.1098/ rspb.2001.1897

Torchin ME, Lafferty KD, Kuris AM (2001) Release from parasites as natural enemies: increased performance of a globally introduced marine crab. Biol Invasions 3:333-345. https://doi.org/10.1023/A:1015855019360 
Verbeke G, Molenberghs G (2000) A Model for Longitudinal Data. In Linear Mixed Models for Longitudinal Data Springer Series in Statistics, New York

Vilà M, Basnou C, Pyšek P, Josefsson M, Genovesi P, Gollasch $\mathrm{S}$, Nentwig W, Olenin S, Roques A, Roy D, Hulme PE (2010) How well do we understand the impacts of alien species on ecosystem services? A pan-European, crosstaxa assessment. Front Ecol Environ 8:135-144. https:// doi.org/10.1890/080083

Viney ME, Steer MD, Wilkes CP (2006) The reversibility of constraints on size and fecundity in the parasitic nematode Strongyloides ratti. Parasitology 133:477-483. https://doi. org/10.1017/S003118200600062X

Wauters LA, Dhondt AA (1989) Body weight, longevity and reproductive success in red squirrels (Sciurus vulgaris). J Anim Ecol 58:637-651. https://doi.org/10.2307/4853

Wauters LA, Lens L (1995) Effects of food availability and density on red squirrel (Sciurus vulgaris) reproduction. Ecol 76:2460-2469. https://doi.org/10.2307/2265820

Wauters LA, Bijnens L, Dhondt AA (1993) Body mass at weaning and juvenile recruitment in the red squirrel. J Anim Ecol 62:280-286. https://doi.org/10.2307/5359

Wauters LA, Tosi G, Gurnell J (2002a) Interspecific competition in tree squirrels: do introduced grey squirrels (Sciurus carolinensis) deplete tree seeds hoarded by red squirrels $(S$. vulgaris)? Behav Ecol Sociobiol 51:360-367. https://doi. org/10.1007/s00265-001-0446-y

Wauters LA, Gurnell J, Martinoli A, Tosi G (2002b) Interspecific competition between native Eurasian red squirrels and alien grey squirrels: does resource partitioning occur? Behav Ecol Sociobiol 52:332-341. https://doi.org/10. 1007/s00265-002-0516-9

Wauters LA, Matthysen E, Adriaensen F, Tosi G (2004) Withinsex density dependence and population dynamics of red squirrels Sciurus vulgaris. J Anim Ecol 73:11-25. https:// doi.org/10.1111/j.1365-2656.2004.00792.x

Wauters LA, Vermeulen M, Dongen SV, Bertolino S, Molinari A, Tosi G, Matthysen E (2007) Effects of spatio-temporal variation in food supply on red squirrel Sciurus vulgaris body size and body mass and its consequences for some fitness components. Ecography 30:51-65. https://doi.org/ 10.1111/j.0906-7590.2007.04646.x

Wauters LA, Githiru M, Bertolino S, Molinari A, Tosi G, Lens L (2008) Demography of alpine red squirrel populations in relation to fluctuations in seed crop size. Ecography 31:104-114. https://doi.org/10.1111/j.2007.0906-7590. 05251.x

Wauters LA, Verbeylen G, Preatoni D, Martinoli A, Matthysen E (2010) Dispersal and habitat cuing of Eurasian red squirrels in fragmented habitats. Popul Ecol 52:527-536. https://doi.org/10.1007/s10144-010-0203-z

Wauters LA, Mazzamuto MV, Santicchia F, Van Dongen S, Preatoni DG, Martinoli A (2019) Interspecific competition affects the expression of personality-traits in natural populations. Sci Rep 9:1-8. https://doi.org/10.1038/s41598019-47694-4

Wilkes CP, Thompson FJ, Gardner MP, Paterson S, Viney ME (2004) The effect of the host immune response on the parasitic nematode Strongyloides ratti. Parasitology 128:661-669. https://doi.org/10.1017/ S0031182004005062

Publisher's Note Springer Nature remains neutral with regard to jurisdictional claims in published maps and institutional affiliations. 